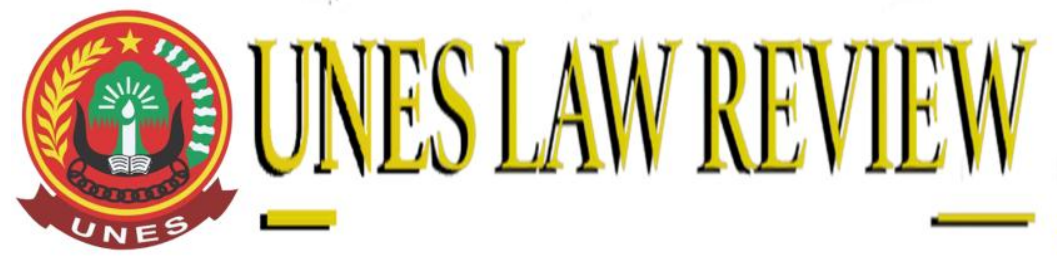

$+6281365118590$ $+6281365118590$

https://review-unes.com/ (7) uneslawreview@gmail.com @ $@$

DOI: https://doi.org/10.31933/unesrev.v4i3

Diterima: 05/02/2022, Diperbaiki: 23/02/2022, Diterbitkan: 01/03/2022

\title{
SOLUSI POTRET PROBLEMATIKA MATERI MUATAN REGULASI DALAM PENANGANAN COVID-19 DI INDONESIA
}

\author{
Ahmad Sabirin', Febrian Duta Adhiyaksa ${ }^{2}$, Janna Shafira Widianti Apcar ${ }^{3}$ \\ ${ }^{1}$ Mahasiswa, Fakultas Hukum, Universitas Trisakti, Jakarta, Indonesia. \\ Email: achmadshobirinfull@gmail.com \\ ${ }^{2}$ Fakultas Hukum, Universitas Trisakti, Jakarta, Indonesia. \\ Email: febrian8989@gmail.com \\ ${ }^{3}$ Fakultas Hukum, Universitas Trisakti, Jakarta, Indonesia. \\ Email: ijannaapcar11@gmail.com
}

Corresponding Author: Ahmad Sabirin

\section{ABSTRACT}

The COVID-19 pandemic has had a tremendous impact, ranging from the economic crisis to public health, which is the government's focus in minimizing the impact of the Covid-19 pandemic. The type of research used in this research is juridical-normative. And the purpose of this research, namely; 1) describe the regulations issued by the Central and Regional Governments in dealing with the Covid-19 Pandemic, 2) and describe solutions to overcome regulatory problems issued by the Central and Regional Governments during the Covid-19 Pandemic. The government in issuing several regulations looks inconsistent, for example; the difference in the definition of PSBB as regulated in PP No. 21 of 2020 with that regulated in the Quarantine Law. Then, regarding the Instruction of the Minister of Home Affairs Number 15 of 2021 which is considered to have neglected the regulations above. Problems with existing regulations, the government needs to break the chain of spread of the Covid-19 pandemic with the product of regulations based on the Tiered Law Theory by Hans Nawiasky. This theory then when associated with problems in Indonesia can make Article 34 paragraph (3) of the 1945 Constitution and Law no. 6 concerning Health Quarantine is a reference for the government in formulating the rules under it, in matters relating to regulations during the Covid-19 pandemic so that it becomes a solution in overcoming the regulatory problems of handling the Covid-19 pandemic.

Keywords: The Problems of Regulatory Portraits during the Covid-19 Pandemic, Handling the Covid-19 Pandemic. 


\section{ABSTRAK}

Wabah pandemi Covid-19 menimbulkan dampak yang luar biasa, mulai dari krisis ekonomi hingga pada kesehatan masyarakat yang menjadi fokus pemerintah dalam meminimalisir dampak pandemi Covid-19 tersebut. Adapun jenis penelitian yang digunkan dalam penelitian ini adalah yuridis-normatif. Dan tujuan dari penelitian ini, yaitu; 1) menggambarkan regulasi yang dikeluarkan oleh Pemerintah Pusat dan Daerah dalam menangani Pandemi Covid-19, 2) dan memaparkan solusi untuk mengatasi problematika regulasi yang dikeluarkan Pemerintah Pusat dan Daerah pada masa Pandemi Covid-19. Pemerintah dalam mengeluarkan beberapa peraturan terlihat tidak konsisten, misalnya; perbedaan definisi PSBB yang diatur dalam PP Nomor 21 Tahun 2020 dengan yang diatur dalam UU Kekarantinaan. Kemudian, mengenai Instruksi Menteri Dalam Negeri Nomor 15 Tahun 2021 yang dinilai mengenyampingkan peraturanperaturan di atasnya. Permasalahan peraturan yang ada, pemerintah perlu memutus rantai penyebaran pandemi Covid-19 dengan produk peraturan-peraturan yang berlandaskan Teori Hukum Berjenjang oleh Hans Nawiasky. Teori ini kemudian apabila dikaitkan dengan permasalahan di Indonesia dapat menjadikan Pasal 34 ayat (3) UUD 1945 dan UU No. 6 tentang Kekarantinaan Kesehatan menjadi acuan bagi pemerintah dalam merumuskan aturan di bawahanya, dalam hal-hal yang berkaitan dengan peraturan di masa pandemi Covid-19 sehingga menjadikan sebagai solusi dalam mengatasi problematika regulasi penangan pandemi Covid-19.

Kata Kunci: Problematika Potret Regulasi di Masa Pandemi Covid-19; Penanganan Pandemi Covid-19

\section{PENDAHULUAN}

Pandemi Covid-19 (Corona Virus Diseas 2019) telah memberikan dampak pada berbagai sektor kegiatan mulai dari perekonomian, sosial kemasyarakatan dan sampai ke bebagai kebijakan pemerintah. Akibat itu semua, pemerintah di tingkat pusat dan daerah telah mengambil berbagai langkah yang salah satunya mengeluarkan berbagai regulasi guna menangani permasalahan wabah pandemi Covid-19 (Ahmad Sabirin, 2020). Namun, dari peraturanperaturan yang diambil tersebut, terdapat fenomena dimana banyak pakar hukum menganggap tidak mencerminkan dengan asas kesesuaian antara jenis, hierarki, dan materi muatan sebagaimana diatut dalam Pasal 5 Undang-Undang Nomor 12 Tahun 2011 jo. Undang-Undang Nomor 15 Tahun 2019 tentang Pembentukan Peraturan Perundang-undangan (UU P3).

Banyaknya peraturan perundang-undangan di masa pandemi Covid-19 yang ambigu, tumpang tindih, sehingga mengakibatkan dalam implementasiannya mengalami kesulitan, terutama untuk merangkul masyarakat dalam mematuhi segala peraturan yang dikeluarkan. Selama masa pandemi Covid-19, telah muncul berbagai peraturan perundang-undangan, seperti Peraturan Pemerintah (PP), Peraturan Presiden (Perpres), Peraturan Menteri (PM) atau Peraturan Kepala Badan, Keputusan Menteri atau Keputusan Kepala Badan dan bahkan Surat Edaran (SE). Hanya saja, dari berbagai peraturan perundang-undangan tersebut menambah permasalahan regulasi di Indonesia karena substansinya tidak sesuai dengan asas-asas pembentukan peraturan perundang-undangan yang baik.

Bivitri Ahli Hukum dari Jentera School of Law memberikan pandangannya, bahwa alasan masyarakat memiliki prilaku dilanggarnya aturan pada Pembatasan Sosial Berskala Besar (PSBB) karena apa yang menjadi produk regulasi pada masa pandemi Covid-19 masih banyak 
terjadi inkonsitensi sehingga akibat daripada itu membingungkan masyarakat yang menjalankan pengimplementasian produk hukum tersebut. Misalnya, hal yang terjadi pada ojek daring sampai peraturan soal pembukaan transportasi dan peraturan mudik yang diperbolehkan, lalu dikemudian diralat lagi oleh pemerintah. Hal ini menjadi salah satu hal yang dapat membingungkan masyarakat. Banyaknya aturan karena dalam pembuatan produk peraturannnya tidak memperhatikan norma hirarki UUP3 (Arif Satrio Nugroho, Republikam, 2021).

Selain itu, kurangnya komunikasi antar lembaga berkepentingan dalam pembuatan regulasi sehingga akibat daripada itu masih terjadi komunikasi-komunikasi yang tidak tersampaikan dengan baik melalui peraturan yang dikeluarkan oleh pemerintah sehingga terjadi banyak peraturan yang tidak konsisten dan wujud peraturan perundang-undangan yang materi muatannya tidak sesuai dengan asas-asas kesesuaian antara jenis dan hierarki. Misal, ada Permen tapi substansinya mengatur ketentuan yang harusnya diatur oleh undang-undang.

Hal tersebut dapat kita lihat pada Pasal 1 Peraturan Pemerintah Nomor 21 Tahun 2020 Tentang Pembatasan Sosial Berskala Besar Dalam Rangka Percepatan Penanganan Corona Virus Disease 2019 (Covid-19), yang mendefinisikan Pembatasan Sosial Berskala Besar (PSBB) "Pembatasan kegiatan tertentu penduduk dalam suatu wilayah yang diduga terinfeksi Corona Virus Disease 2019 (Covid-19) sedemikian rupa untuk mencegah kemungkinan penyebaran Corona Virus Disease 2019 (Covid-19)”. Sedangkan, Pasal 1 Ayat (11) Undang-undang Nomor 6 Tentang Kekarantinaan Kesehatan, mendefinisikan PSBB dengan "Pembatasan Sosial Berskala Besar adalah pembatasan kegiatan tertentu penduduk dalam suatu wilayah yang diduga terinfeksi penyakit dan/atau terkontaminasi sedemikian rupa untuk mencegah kemungkinan penyebaran penyakit atau kontaminasi",

Kita dapat melihat bahwasannya pada PP No. 21 Tahun 2020 lebih mendefinisikan PSBB secara spesifik, sedangkan pada UU Nomor 6 tentang Kekarantinaan Kesehatan mendefinisikan PSBB secara umum, tentu hal ini dapat mencederai regulasi karena ketidakkonsistenan pemerintah dalam mengeluarkan produk peraturannya. Ironinya, pemerintah lebih menggunakan PP dibandingkan UU, hal ini tentu melanggar hirarki perundang-undangan yang ada. Selain itu, terdapat juga Instruksi Menteri Dalam Negeri No. 15 Tahun 2021 tentang Pemberlakuan Pembatasan Kegiatan Masyarakat Darurat Corona Virus Disease 2019 di wilayah Jawa dan Bali. Aturan ini, dibuat berdasarkan arahan presiden. Dimana pada aturan tersebut tertulis dikeluarkannya karena arahan presiden agar pelaksanaan PPKM dapat disesusikan dengan kondisi penyebaran pandemi Covid-19.

Terdapat pula pada pasal 55 ayat (1) UU Nomor 6 tentang Kekarantinaan Kesehatan yang berbunyai "Selama dalam Karantina Wilayah, kebutuhan hidup dasar orang dan makanan hewan ternak yang berada di wilayah karantina menjadi tanggung jawab Pemerintah Pusat. Jika, kita membandingkan dengan PP, Instruksi Menteri Dalam Negeri dan peraturan lainya yang dikeluarkan di masa pandemi Covid-19 tidak mengatur bahwa pemerintah akan menanggung semua pembiayaan selama PSBB. Hal ini tentu menjelaskan, bahwa peraturan-peraturan yang dikeluarkan di masa pandemi Covid-19 masih terlihat inkonsisten. 
Keberadaan peraturan perundang-undangan yang inkonsiten di atas, tentu menyalahi konsep negara hukum yang mengharuskan peraturan yang dibentuk mestinya tunduk pada aturan main dalam pembentukan peraturan perundang-undangan. Keberadaan cita negara hukum menjadi sangat penting bagi pemerintah dalam memutuskan dan mengelurakan suatu produk hukum yakni peraturan. Melalui pedoman negara hukum, maka perumusan suatu kebijakan dalam norma hukum, baik itu berupa keputusan (beschicking) dan peraturan (regeling) ( $\mathrm{P}$. Burgess, 2021) ' Oleh karena itu, mengingat peraturan yang ada di masa pandemi Covid-19 sangat penting, maka harus dibentuk berdasarkan pada hirarki peraturan yang ada sehingga peraturan yang diciptakan akan berdampak pada ketertiban dan keamanan di masyarakat. Hal ini, sejalan dengan pendapat yang dikemukakan oleh Immanuel Kant, bahwa "memahami negara hukum sebagai Nachtwakerstaat atau Nachtwachterstaat (negara penjaga malam), yang tugasnya adalah menjamin ketertiban dan keamanan masyarakat.”( Tahir Azhari, 1995, 20-21)

Banyaknya peraturan yang inkonsisten sehingga implementasinya menjadi tidak jelas. Misalnya, dapat dilihat adanya tarik ulur kewenangan antara pemerintah pusat dan Pemerintah Provinsi DKI Jakarta. Pemerintah Provinsi menginginkan agar penanganan pandemi Covid-19 menjadi domain mutlak pemerintah daerahnya, sedangkan Pemerintah pusat menghendaki agar penanganan Covid-19 terpusat di Kementerian Kesehatan. Selain itu, dapat dilihat kasus Pemerintah daerah Provinsi Jawa Barat yang menginginkan agar pemembukaan informasi terkait pandemi Covid-19 juga menjadi bagian kewenangannya.

Berbagai permasalahan yang telah dipaparkan di atas, sejatinya terdapat potret kedaruratan permasalahan dari segi regulasi dalam penanganan pandemi Covid-19. Padahal, sebagai negara hukum, adanya ketentuan tertulis menjadi syarat utama. Oleh karena itu, penting untuk dicarikan solusi dengan terlebih dahulu mengkaji akar permasalahannya untuk kemudian dikaitkan dengan teori terkait dan aturan main yang terdapat dalam berbagai peraturan perundang-undangan, khususnya undang-undang mengenai pembentukan peraturan perundangundangan.

Berdasarkan persoalan pada latar belakang tersebut, bahwa penanganan pandemi Covid19 di Indonesia belum maksimal sehingga para penulis dalam hal ini, akan memaparkan hal-hal berkaitan dengan bentuk problematikan pengaturan yang dikeluarkan oleh Pemerintah Pusat dan Daerah dalam menangani Pandemi Covid-19. Selanjutnya, setalah pemaparan berdasarkan pada problematika tersebut, para penulis memberikan solusi dalam mengatasi problematika regulasi yang dikeluarkan Pemerintah Pusat dan Daerah pada masa Pandemi Covdi-19 demi menjaga kuutuhan berbangsan serta mendukung pemutusan penyeberan pandemi Covid-19.

\section{METODE PENELITIAN}

Jenis penelitian ini merupakan jenis penelitian yuridis-normatif, yaitu penelitian hukum yang dilakukan dengan cara meneliti dari bahan-bahan pustaka atau data sekunder (Abdulkhadir Muhammad, 2004, 5). Sebagai bahan dasar untuk diteliti. yaitu dengan cara mengadakan penelusuran terhadap berbagai peraturan perundang-undangan terkait peraturan di era Pandemi Covid-19. Kemudian ditelusuri juga literatur-literatur yang berkaitan dengan permasalahan terkait inkonsitensi dan tumpang tindih peraturan. Hasil dari penelitian yuridis-normatif tersebut, 
disajikan secara deskriptif melalui pemaparan yang menggambarkan selengkap mungkin tentang: 1). Permasalahan terkait kebijakan pertauran pada era Pandemi Covid-19; 2). Serta solusi agar tidak terjadi tumpang tindih baik secara vertikal maupun horizontal, sehingga melalui kedua paparan tersebut, diharapkan produk peraturan yang dihasilakan nanti akan menjadi instrument efektif sehingga mampu meningkatkan efektivitas dalam penanganan Pandemi Covid-19.

\section{HASIL DAN PEMBAHASAN}

\section{Bentuk (Eksistensi) Peraturan dalam Penanganan Pandemi Covid-19}

Bentuk peraturan dalam mengantisipasi wabah pandemi Covid-19 di Indonesia masih menjadi PR bersama, terutama dalam hal implementasian peraturannya. Persoalan tersebut karena peraturan yang dikeluarkan oleh pemerintah terlihat inkonsiten dengan peraturanperaturan lainya meskipun kebijakan tersebut dikeluarkan demi menghindari kenaikan angka pandemi Covid-19. Menariknya, meskipun lahir dari satu jenis peraturan yang sama, namun dalam implementasinya muncul istilah-istilah yang berbeda. Misalnya, terkait dengan pembatasan kegiatan masyarakat, di mana landasan hukumnya bersumber dari Peraturan Pemerintah (PP) Nomor 21 Tahun 2020 tentang Pembatasan Sosial Berskala Besar dalam Rangka Percepatan Penanganan Covid-19. Akan tetapi, ironisnya istilah yang digunakan oleh pemerintah pusat dan pemerintah daerah terlihat berbeda-beda. Misalnya Pemerintah DKI Jakarta pernah menggunakan istilah PSBB Transisi, di Jawa Barat dengan istilah PSBB Proporsional, sedangkan di daerah Kota Bogor menggunkan istilah Pembatasan Sosial Berskala Mikro dan Komunitas (PSBMK), dan di Kabupaten Bogor menggunakan istilah PSBB PraAdaptasi Kehidupan Baru (Fauziah Mursidah, 2021).

Adapun uraian lengkap mengenai bentuk dan eksistensi peraturan yang dikeluarkan oleh Pemerintah Pusat dalam menangani pandemi Covid-19, ialah sebagai berikut:

1. Peraturan terkait Pembatasan Sosial Berskala Besar (PSBB)

Pada saat pertama kali Indonesia mengalami bencana pandemi Covid-19 bermula semakin meningkatnya masyarakat yang positif sehingga pemerintah dengan segera menerbitkan Peraturan Presiden (PP) Nomor 21 Tahun 2020 tentang Pembatasan Sosial Berskala Besar (PSBB) dalam rangka Pencepatan Penangan Pandemi Covid-19 yang mulai ditekankan pada tanggal 31 Maret 2020. PSBB tersebut merupakan strategi pertama pemerintah untuk menekan angka lonjakan penyebaran pandemi Covid-19 di Indonesia. Namun, PSBB tersebut hanya diterapkan di lingkup wilayah tertentu yang memiliki penyebaran Covid-19 yang cukup banyak dan dikatakan dengan istilah zona merah berdasarkan pada tingkat lonjakan masyarakat yang positif Covid-19.

Pembatasan tersebut melingkupi kegiatan-kegiatan masyarakat dalam berbagai bidang, seperti pembatasan kegiatan dalam bidang peribadahan (keagamaan), pendidikan (sekolah), kantor, hingga transportasi, dan hanya sektor esensial yang dapat beroperasi penuh dengan memperhatikan protokol kesehatan yang ketat.

Istilah PSBB ini sebenarnya terdapat dalam Pasal 59 UU Nomor 6 Tahun 2018 tentang Kekarantinaan Kesehatan, dan diatur lebih lanjut dalam PP Nomor 21 Tahun 2020 
tentang PSBB, namun PP ini tidak efektif dalam palaksnaan pencegahan covid-19, karena materi yang diatur sangat sederhana. Hal ini senada dengan pendapat Direktur Jaringan dan Advokasi Pusat Studi Hukum dan Kebijakan (PSHK) Fajri Nursyamsi menjelaskan, bahwa keberadaan PP No. 21 Tahun 2020 tidak memadai untuk melaksanakan percepatan penanganan Covid-19, karena subtansi sangat terbatas, sehingga tidak memadai untuk melaksanakan percepatan penanganan Covid-19 (Rahmat, 2021).

2. Peraturan terkait Pemberlakukan Pembatasan Kegiatan Masyarakat (PPKM)

PPKM mulai diterapkan pemerintah sejak pada tanggal 11 Januari 2021 di 7 (tujuh) provinsi untuk daerah Jawa-Bali, hal tersebut karena daerahnya terindikasi dengan tingkat penularan tinggi dibandingkan dengan daerah-daerah provinsi lainya. Hal ini, mengingat karena daerah Jawa-Bali menjadi daerah penyanggah dari daerah-daerah lainya.

Adapun regulasi yang diimplementasikan mencangkup sebesar 75 (tujuh puluh lima) persen Work from Office (WFO) di sektor non-esensial, dan sebesar 100 (seratus) persen WFO di sektor-sektor yang esensial. Misalnya, pada tempat ibadah mempunyai atau diberlakukan pembatasan maksimal 50 (lima puluh) persen, serta seluruh Kegiatan Belajar Mengajar (KBM) dilakukan dan diterapkan secara daring (Maya Sahurina, 2021).

Adapun dasar hukum dalam penerapan PPKM ini terdapat pada Instruksi Menteri Dalam Negeri (Imandagri) Nomor 1 Tahun 2021. Namun, peraturan tersebut tidak sesuai dengan aturan di atasnya yaitu UU Nomor 6 Tahun 2018 tentang Kekarantinaan Kesehatan karena dalam UU tersebut menggunakan istilah PSBB, tidak menggunakan istilah PPKM. Selain itu, dalam UU Kekarantinaan Kesehatan, menteri yang berwenang adalah Menteri Kesehatan, namun dalam Imendagri tersebut menteri yang berwenang adalah Menteri Dalam Negeri. Jadi, sebenarnya Imendagri ini tidak sesuai dan bertentangan dengan aturan yang di atasnya.

Jika mengekaji subtansi PPKM ini, sebenarnya sama dengan Kekarantinaan Kesehatan yang di atur dalam UU Nomor 6 Tahun 2018, namun pemerintah mengganti istilah Karantina Darurat menjadi PPKM dengan membuat Imendagri tersebut, hal ini tidak lain karena pemerintah tidak ingin menanggung kewajiban untuk menyediakan kebutuhan dasar orang dan makanan hewan sesuai pasal 55 ayat (1) UU Nomor 6 Tahun 2018. Di sisi lain, dalam menerapkan sanksi terhadap pelanggar, pemerintah menggunakan UU tersebut.

3. Peraturan terkait Pemberlakukan Pembatasan Kegiatan Masyarakat (PPKM) Mikro

Setelah terjadinya lonjakan pandemi Covid-19, mengakibatkan pemerintah semakin membatasi dan memperketat kegiatan masyarakat di luar. Kebijakan yang dikeluarkan PPKM Mikro mulai diterapkan untuk tujuh provinsi pada daerah Jawa-Bali. Dimana daerah ini termasuk pada daerah yang memiliki kegiatan masyarakat yang padat, di sisi lain juga jumlah penduduk yang cukup banyak dibandingkan dengan daerah-daerah lainya. Adapun kebijakan tersebut dengan menggunakan strategi penanganan berbasis komunitas-komunitas terkecil di RT/RW.

Adapun regulasi yang diterapkan meliputi kapasitas rumah ibadah dan dine-in dengan maksimal 50 (lima puluh) persen, kegiatan pusat perbelanjaan juga dibatasi hingga dengan 
sampai pukul 21.00. Dan Work from Office (WFO) dengan maksimal 50 (lima puluh) persen. Demikian semakin kebelakang regulasi yang dikeluarkan oleh pemerintah semakin membatasi kegiatan-kegiatan masyarakat, hal ini karena berkaca pada penerapan regulasi sebelumnya belum maksimal dan tidak berdampak signifikan dalam menurunkan angka masyarakat yang positif Covid-19 (Rendika, 2021).

Subtansi aturan PPKM mikro ini merupakan tindak lanjut dari PPKM Jawa Bali, yang menjadi dasar hukum atas peraturan ini diatur pada Imendagri Nomor 3 Tahun 2021. Seperti dasar hukum mengenai PPKM Jawa-Bali, dasar Hukum PPKM ini masih tidak sesuai dengan aturan di atasnya, yaitu UU Nomor 6 Tahun 2018. Dimana tidak ada pasal dalam UU tersebut yang mengatur PPKM mikro ini. Yang membedakan dengan aturan PPKM JawaBali hanya mengenai aturan yang lebih mikro sampai ke tingkat RT/RW.

4. Peraturan Penebalan Pemberlakukan Pembatasan Kegiatan Masyarakat (PPKM) Mikro

Regulasi ini diterapkan karena berdasarkan pada semakin banyak kasus pandemi Covid-19 pasca libur lebaran, dengan demikian pemerintah berinisiatif untuk memperketat dan membatasi kegiatan masyarakat. Dimana regulasinya yang meliputi dan menekan dengan dine-in maksimal 25\% (dua lima persen) dari kapasitasnya. Sedangkan WFO hanya diberikan dengan maksimal 25\% (dua lima persen) bagi kantor-kantor yang berada di zona merah khususnya di daerah Jakarta dan Jawa. Di sisi lain, diberlakukannya dengan larangan oprasional tempat-tempat ibadah dan sekolah tatap muka di zona merah. Penebalan PPKM Mikro ini mulai diberlakukan pada tanggal 22 Juni hingga 5 Juli 2021 (Rendika, 2021). Penebalan PPKM mikro ini didasarkan pada Imendagri Nomor 14 Tahun 2021, di dalam Imendagri ini pengaturan aktivitas masyarakat diatur lebih ketat dibandingkan dengan aturan PPKM Mikro sebelumnya.

5. Peraturan terkait Pemberlakukan Pembatasan Kegiatan Masyarakat (PPKM) Darurat Jawa dan Bali

Setelah Penebalan PPKM Mikro, namun pemerintah menggunakan istilah PPKM Darurat dengan semakin memperketat kegitan masyarakat, khususnya di daerah Jawa dan Bali. Aturan yang digunakan pada PPKM darurat ini meliputi 100\% (seratus persen) sektor pekerjaan dilakukan WFH yang termasuk di sektor non-esensial, dan sedangkan yang termasuk pada bidang esensial maksimal 50\% (lima puluh persen) WFO.

Berbeda pada regulasi sebelum-belumnya pada PPKM darurat ini menutup pusat perbelanjaan seperti mall, restoran dan hanya menerima makan delivery/take away. Pada PPKM Darurat ini telah diberlakukan pada tanggal 3 (tiga) sampai dengan tanggal 20 (dua puluh) Juli 2021 di daerah Jawa dan Bali (Fitriah, 2021). PPKM Darurat ini diatur dalam Imendagri No 15 Tahun 2021. Aturan ini sangat ketat dibandingkan dengan aturan mengenai PPKM mikro. Misalnya terkait pekerja non-esensial, dalam aturan ini pekerja tersebut harus 100\% WFH (Work From Home). 
6. Peraturan terkait Pemberlakukan Pembatasan Kegiatan Masyarakat (PPKM) Level 1, Level 2, Level 3, dan Level 4

Pemerintah dalam hal ini tidak lagi menggunakan istilah PPKM Darurat. Tetapi, menggunakan istilah PPKM Darurat Level 1, Level 2, Level 3 dan Level 4 sampai saat ini. Perpanjangan mulai dari Level 1 hinggal Level 4 telah dilakukan pemerintah hingga sampai 16 Agustus 2021. Pada kondisi ini pemerintah membatasi kegiatan dalam berbagai sektor. Misal, pada sektor administrasi perkantoran hanya memberikan 25 (dua lima) persen. Namun, setelah melangkah pada Level 3 dan Level 4 pemerintah mewajibkan perkantoran $100 \%$ (seratus persen) WFH. Sedangkan untuk sektor esensial yang pada saat Level 1 dan 2 memberikan maksimal 50\% (lima puluh persen) WFO, setelah beranjak ke Level 3 dan Level 4 menurunkan menjadi 25\% (dua puluh lima persen) (Rosy, 2021).

Demikian, tujuan daripada istilah tersebut sebenarnya untuk mempermudah pemerintah daerah dalam menerapkan regulasi di daerahnya masing-masing atas dasar bahwa tidaklah semua daerah berada pada keadaan yang sama. Maka, daerah-daerah yang dimaksud berada pada daerah yang aman sehingga bisa dengan segera masuk ke dalam zona aman. Dengan demikian, dapat melakukan kegiatan bertahap di beberapa bidang yang memungkinkan. Namun, jika kita merujuk pada UU Kekarantinaaan Kesehatan istilah PSBB ini bahwa PSBB adalah pembatasan kegiatan tertentu penduduk pada suatu wilayah yang diduga terifeksi penyakit dan/atau terkontaminasi, sedemikian rupa untuk mencegah kemungkinan penyakit atau kontaminasi. Pada pasal 59 Ayat (3) PSBB meliputi (1) peliburan sekolah dan tempat kerja; (1) pembatasan kegiatan keagamaan; dan/atau (3) pembatasan kegiatan di tempat atau fasilitas umum. Jika meliahat kembali subtansi-subtansi yang ada pada PP yang berkaitan dengan PSBB masih terlihat banyak terjadi ketidakkesesuaian. Misalnya,

Ketidaksesuain itu, terlihat pada istilah-istilah PSBB yang dipakai hingga saat ini terlihat perbedaan istilah, serta tanggung jawab pemerintah terkait dengan pembiayaan makanan dan keperluan masyarakat dan binatang peliharaan dimana pada UU No 6 Tahun 2018 tentang Kekarantinaan Kesehatan menjadi tanggung jawab pemerintah, namun pada PP yang telah dikeluarkan oleh pemerintah tidak mengatur hal tersebut. Akibatnya, tingkat kepercayaan masyarakat terhadap pemerintah rendah sehingga banyak masyarakat yang melanggar PSBB atau PPKM dan dampak daripada itu angka kematian dan positif Covid-19 pun semakin banyak mulai awal terjadinya pandemi Covid-19 sampai pada pemberlakuan PPKM Darurat Jawa dan Bali.

Namun, disayangkan masih terdapat beberapa subtansi dari UU Nomor 6 Tahun 2018 Tentang Kekarantinaan Kesehatan yang masih memiliki pebedaan pandangan. Sebagai salah satu contoh ketidaksesuain definisi PSBB menurut PP Nomor 21 Tahun 2020, dalam hal ini sifat yang didefinisikan bersifat spesifik; "Pembatasan kegiatan tertentu penduduk dalam suatu wilayah yang diduga terinfeksi Corona Virus Disease 2019 (Covid-19) sedemikian rupa untuk mencegah kemungkinan penyebaran Corona Virus Disease 2019 (Covid-19)”.

Sedangkan, Definisi PSBB dalam UU Kekarantinaan Kesehatan memberikan pengertian yang lebih umum "Pembatasan Sosial Berskala Besar adalah pembatasan kegiatan tertentu 
penduduk dalam suatu wilayah yang diduga terinfeksi penyakit dan/atau terkontaminasi sedemikian rupa untuk mencegah kemungkinan penyebaran penyakit atau kontaminasi”.

Selain itu, terdapat juga Instruksi Menteri Dalam Negeri No. 15 Tahun 2021 tentang Pemberlakuan pembatasan kegiatan masyarakat darurat Corona Virus Disease 2019 di wilayah Jawa dan Bali. Aturan ini, dibuat berdasarkan arahan presiden dimana pada aturan tersebut tertulis dikeluarkannya karena arahan Presiden agar pelaksanaan PPKM dapat disesuaikan dengan kondisi penyebaran pandemi Covid-19. Demikian yang menjadi berlakunya Instruksi Menteri Dalam Negeri Nomor 15 Tahun 2021 yang mengenyampingkan peraturan-peraturan di atasnya.

Misalnya lagi, pada pasal 55 Ayat (1) UU Nomor 6 tentang Kekarantinaan Kesehatan yang berbunyi "Selama dalam Karantina Wilayah, kebutuhan hidup dasar orang dan makanan hewan ternak yang berada di wilayah karantina menjadi tanggung jawab Pemerintah Pusat. Apabila kita bandingkan dengan PP, Instruksi Menteri Dalam Negeri dimana tidak mengatur bahwa pemerintah akan menanggung semua pembiayaan selama PSBB/PPKM. Hal ini tentu seolah menjelaskan peraturan-peraturan yang dikeluarkan di masa pandemi Covid-19 masih terlihat inkonsisten.

Dimensi lain yang telihat inkonsisten, ialah pada penggunaan istilah dan cenderung berubah-ubah dalam regulasi penanganan pandemi Covid-19 sebagaimana penulis uraikan pada sub bab di atas. Istiah yang digunakan yang berbeda-beda pada regulasi tersebut, disebabkan dalam pembentukannya tidak berpedoman pada hierarki norma perundang-undangan yang sifatnya berlapis dan berjenajang. Sebagaiman dikemukakan Hans Nawiasky, bahwa terdapat IV kelompok norma hukum dan terhadap konteks penanganan Covid-19 maka aturan-aturan pelaksana dan aturan otonomnya tidak boleh bertentangan dengan UU No. 6 Tahun 2018 yang merupakan formall gesetz (undang-undang).

Pemerintah seharusnya dapat bersikap konsisten terhadap prioritas yang ingin didahulukan dalam menangani wabah virus Covid-19 ini sendiri, apakah pemerintah ingin memprioritaskan kesehatan warga negara atau perekonomian negara terlebih dahulu. Apabila pemerintah tidak dapat memilih antara kesehatan atau perekonomian yang ingin dituntaskan terlebih dahulu, tentu peraturan-peraturan yang dibuat oleh pemerintah akan tumpang tindih tanpa tahu arahnya akan kemana.

Dilihat dari penerbitan Peraturan Menteri Perhubungan No 18 Tahun 2020 bertentangan dengan Peraturan Menteri Kesehatan (Permenkes) Nomor 9 Tahun 2020 yang menjadi dasar penerapan PSBB. Permenkes No 9 Tahun 2020 fokus pada penanganan pandemi Covid-19 yang melarang ojek online mengangkut penumpang, sedangkan Peraturan Menteri Perhubungan (Permenhub) Nomor 18 Tahun 2020 memperbolehkan ojek online mengangkut penumpang dengan alasan agar perekonomian tetap berjalan. Selain itu dalam kasus imbauan pemerintah pusat kepada masyarakat mengenai larangan mudik, tetapi masih diperbolehkan dengan syarat bagi yang tetap mudik statusnya menjadi Orang Dalam Pemantauan (ODP) dan wajib mengisolasi diri sesampainya di kampung halaman selama 14 hari, dengan tujuan agar roda perekonomian di daerah tetap berjalan. 
Akan tetapi banyak pemerintah daerah yang mengharapkan agar larangan mudik diberlakukan secara tegas, mengingat angka penyebaran wabah Covid-19 yang sangat tinggi, masalah ini jelas terlihat lemahnya koordinasi antara pemerintah pusat dengan pemerintah daerah, hal ini menimbulkan inkonsistensi kebijakan. Inkonsistensi pemerintah dalam menangani permasalahan perekonomian dan kesehatan seperti inilah yang mengakibatkan upaya pemerintah dalam menangani pandemi Covid-19 tidak kunjung membuahkan hasil yang signifikan.

Berbeda dengan Surat Edaran (SE) Nomor 47 Tahun 2021 tentang Petunjuk Pelaksanaan Perjalanan Internasional dengan Transportasi Udara tersebut, dalam Surat Edaran Satgas Penanganan Covid-19 Nomor 13 Tahun 2021, pemerintah melarang masyarakat melakukan perjalanan antarkota atau kabupaten atau provinsi dan/atau negara untuk tujuan mudik dimana dalam hal ini seharusnya apabila dilakukan pemberbatasan warga negara terhadap kegiatan yang dilakukan dalam negeri sendiri, tentu harus diikuti dengan pemberbatasan kedatangan warga negara asing dari luar negeri itu sendiri.

Tidak ada perbedaan yang cukup signifikan dalam pelaksanaannya di lapangan dari kedua istilah yang digunakan oleh pemerintah pusat tersebut, selain mengenai waktu makan ditempat atau dine-in selama maksimal dua puluh menit sebagaimana dengan yang tertuang pada Intruksi Menteri Dalam Negeri Nomor 27 Tahun 2021 tentang Pemberlakuan Pembatasan Kegiatan Masyarakat Level 4, Level 3, dan Level 2 Corona Virus Disease 2019 di Wilayah Jawa dan Bali.

Dalam hal ini, seharusnya bukan istilah-istilah yang diperbaharui saja, melainkan konsistensi pemerintah pusat terhadap aturan pelaksanaannya di lapangan. Sebagaimana dengan teori berjenjang oleh Hans Kelsen, konsitensi dari hierarki norma yang paling tinggi hingga ke hierarki norma di bawahnya sangat dibutuhkan dimana dalam hal ini, konsistensi pemerintah pusat tentu akan mempengaruhi bagaimana aparat pelaksana di lapangan mengimplementasikan kebijakan-kebijakan yang dibuat oleh pemerintah pusat tersebut.

Serangkaian kebijakan inkonsisten yang dibuat oleh pemerintah, jelas terlihat bahwa aturan-aturan tersebut dibuat tidak berdasarkan permasalahan yang terjadi, sehingga menghasilkan aturan yang buruk. Lemahnya koordinasi dan sinkronisasi antarinstansi juga menimbulkan kesulitan dalam penerapan di lapangan. Rangkaian inkonsistensi ini dapat menimbulkan ketidakpercayaan sosial (sosial distust) kepada pemerintah dan legitimasi pemerintah bisa jatuh.

\section{Solusi Permasalahan Inkonsitensi Pengaturan pada Masa Pandemi Covid-19 Berdasarkan} Teori Hukum Berjenjang

Rousseau berpendapat bahwa kedaulatan itu berdasarkan kemauan umum (volonte generale) dan menjelma dengan perantara undang-undang yang memiliki empat sifat, sebagai berikut (Muhammad Yamin, 1982, 62-63):

1. Unite adalah satu dimana rakyat berhak memerintah dan berhak untuk tidak diperintah. Kesatuan itu terlihat dalam pembuatan undang-undang dan penuntutan keadilan. 
2. Indivisibilitie adalah kedaulatan dimana kedaulatan tidak dapat dipecah-pecah, seperti negara atau rakyat yang melaksanakan dan memegang segala ketentuan tentang kedaulatan.

3. Inalienabilitie adalah kedaulatan tidak boleh dijual, digadai atau dihadiahi karena kedaulatan dimiliki bangsa secara turun-temurun sesuai dengan tabiat kedaulatan itu sendiri.

4. Imprescriptibilite adalah kedaulatan tetap ditangan rakyat, tidak susut dan tidak berkurang. Kekuasaan tertinggi bersifat kekal dan abadi, sama dengan timbul dan tenggelamnya rakyat.

Rosseau juga mengemukakan kedaulatan rakyat mengimplikasikan dua anggapan, yaitu penolakan terhadap segala wewenang di atas rakyat dan tuntutan agar segala kekuasaan yang ada dan identik dengan kehendak rakyat di pihak lainnya. Jadi, negara tidak berhak untuk meletakkan kewajiban atau pembatasan apa pun pada rakyat. Rakyat berwenang penuh untuk menentukan dirinya sendiri dan tidak ada yang mempunyai wewenang terhadap rakyat (Frans Magnis Suseno, 1999, 240-241).

Apabila dikaitkan dalam konteks kenegaraan, maka dapat dipahami bahwa kedaulatan rakyat menempatkan kekuasaan tertinggi untuk mengatur pemerintahan negara pada rakyat. Jadi, rakyat menentukan sendiri bagaimana mereka harus diperintah. Dalam sistem ketatanegaraan Indonesia, implementasi kedaulatan rakyat tertuang dalam Pasal 1 ayat (2) Undang-Undang Dasar (UUD) 1945. Secara tekstual ketentuan dalam pasal tersebut mengandung makna bahwa pelaksanaan kedaulatan rakyat hanya dapat dilaksanakan bila sesuai dengan ketentuan yang telah diatur dalam UUD 1945.

Pengertian lain, pelaksanaan kedaulatan rakyat dibatasi dan harus tunduk pada aturan konstitusi. Jadi, terdapat supremasi konstitusi di atas kedaulatan rakyat dimana ketentuan ini mengandung asas demokrasi konstitusional. Berdasarkan teori norma oleh Hans Nawiasky, UUD 1945 berada pada tingkatan kedua sebagai pedoman aturan negara diikuti dengan aturan dasar negara berupa undang-undang formal yang mengikat warga negara. Selanjutnya, peraturan pelaksana pada tingkatan terakhir dimana pada prinsipnya segala pelaksanaan dalam peraturan tidak melangkahi aturan dasar negara (UU) dan harus tetap pada hirarki Peraturan Perundangundangan (PPU).

Bekaitan dengan hirarki PPU sampai saat ini, regulasi yang dikeluarkan di masa pandemi Covid-19 cenderung tidak memperhatikan PPU. Peraturan pelaksanaan selalu melangkahi undang-undang formal. Hal tersebut terlihat pada inkonsistensi yang dilakukan oleh pemerintah dalam menangani pandemi Covid-19. Pemerintah kerap kali mengubah istilah pembatasan kegiatan masyarakat, seperti pemberlakuan Pembatasan Sosial Berskala Besar (PSBB), kemudian Pemberlakuan Pembatasan Kegiatan Masyarakat (PPKM) Jawa-Bali, lalu Penebalan Pemberlakuan Kegiatan Masyarakat (PPKM) Mikro, Pemberlakuan Pembatasan Kegiatan Masyarakat (PPKM) Darurat, Pemberlakuan Pembatasan Kegiatan Masyarakat (PPKM) Level 1, Level 2, Level 3, dan Level 4 tanpa memperhatikan konsistensi dari setiap regulasi yang ditetapkan. 
Dalam hal ini, dibutuhkan penerapan daripada Teori Berjenjang atau Berlapis oleh Hans Nawiasky. Hans Nawiasky membagi suatu hierarki norma hukum menjadi empat kelompok dari aturan yang paling tinggi hingga aturan-aturan dibawahnya. Keempat kelompok tersebut meliputi Norma Fundamental Negara (Staatsfundamentalnorm), Aturan Dasar Negara/Aturan Pokok Negara (Staatsgrundgesetz), Undang-Undang 'formal' (Formell Gesetz), serta Aturan Pelaksana dan Aturan Otonom (Verordnung \& Autonome Satzung).

Teori ini dapat digunakan oleh pemerintah sebagai cerminan untuk bersikap konsisten terhadap peraturan yang dibuat, terutama pada masa penanganan pandemi Covid-19, pemerintah menjadikan Pasal 34 ayat (3) UUD 1945 sebagai norma pada kelompok III hierarki norma hukum sebagai pedoman dalam menetapkan aturan pada kelompok IV hierarki norma hukum. Sejalan dengan Frederich Julius Stahl dalam karyanya yang berjudul Philosophie des Rechts, yang terbit pada tahun 1878, unsur-unsur paham negara hukum baru sebagai penyempurnaan dari paham negara hukum.

Implementasi dari hierarki PPU pada teori berjenjang akan membimbing pada peraturan yang sistematis dan tidak membingungkan masyarakat mengingat Indonesia sebagai negara hukum yang menjunjung nilai-nilai hak asasi mansuia (HAM) dan keadilan. Hal ini memiliki relevansi dengan pendapat Immanuel Kant, yang menjelaskan unsur-unsur dari negara hukum meliputi: (a) perlindungan hak-hak asasi manusia; (b) pemisahan dan pembagian kekuasaan untuk menjamin hak-hak itu; (c) pemerintahan berdasarkan peraturan perundang-undangan; dan (d) peradilan administrasi dalam perselisihan (Miriam Budiarjo, 2006, 57-58). Menurut Scheltema, unsur-unsur rechtstaat adalah sebagai berikut (Miriam Budiarjo, 2006, 90):

1. Kepastian hukum;

2. Persamaan;

3. Demokrasai;

4. Pemerintahan yang melayani kepentingan umum.

Hierarki norma yang dicetuskan oleh Hans Nawiasky ini apabila dikaitkan dengan peraturan pemerintah selama masa pandemi Covid-19, maka Undang-Undang 'formal' (Formell Gesetz) pada permasalahan ini seharusnya dapat merujuk pada Pasal 34 ayat (3) UUD 1945 yang berbunyi "Negara bertanggung jawab atas penyediaan fasilitas pelayanan kesehatan dan fasilitas umum yang layak."

Warga negara yang terjangkit virus Covid-19 berhak mendapatkan fasilitas pelayanan yang mudah dan optimal, terutama pada pasien kritis. Untuk mewujudkan hal tersebut, pemerintah perlu menyiapkan tempat berikut fasilitas dan tenaga medis yang mampu menampung lonjakan kasus akibat dari virus Covid-19 sebagaimana diatur dalam Pasal $24 \mathrm{C}$ ayat (1) UUD 1945 memberikan pemahaman bahwa secara substansi hukum, adanya hierarki yang lebih tinggi dari UUD 1945 sebagai Staatsgrundgesetz atau aturan pokok negara dan/atau aturan dasar negara dibandingkan dengan formeel Gesetz atau undang-undang, negara bertanggung jawab dalam penyediaan fasilitas pelayanan kesehatan yang layak, akan tetapi dalam hal ini pemerintah berpanduan pada peraturan pelaksana yang tidak memberikan hak-hak tersebut. 
Kedarutan Kesehatan Masyarakat yang Meresahkan Dunia (KKMMD) atau Public Health Emergency of International Concern (PHEIC) dengan Case Fatality Rate (CFR) yang tinggi hingga mencapai $4.6 \%$ di seluruh dunia, maka cukup sulit bagi pemerintah untuk mewujudkan hak warga negara yang tertuang pada pasal tersebut karena keterbatasan rumah sakit, fasilitas, serta tenaga medis.

Maka, perlu adanya kebijakan secara konsisten baik pemerintah pusat, maupun pemerintah daerah dalam hal memperlambat bahkan menghentikan laju penyebaran. Konsistensi oleh pemerintah tersebut dapat dituangkan melalui Aturan Pelaksana dan Aturan Otonom (Verordnung and Autonome Satzung). Perlu kiranya memperbaiki peraturan-peraturan terlebih dahulu dengan membentuk suatu norma yang dapat mengendalikan dan mengarahkan sehingga tidak terjadi inkonsitensi dalam peraturan.

Demikian, norma hukum berjenjang dan berlapis dapat menjadi salah satu solusi yang tepat, norma ini dalam suatu hierarki (tata susunan), dalam arti, suatu norma yang lebih rendah berlaku, bersumber dan berdasar pada norma yang lebih tinggi, norma yang lebih tinggi berlaku, bersumber dan berdasar pada norma yang lebih tinggi lagi, demikian seterusnya sampai pada suatu norma yang tidak dapat ditelusuri lebih lanjut dan bersifat hipotetis dan fiktif yaitu Norma Dasar (Grundnorm) (Maria Farida Indrati, 2007,41).

Selain itu tersirat juga makna norma hukum yang lebih rendah (undang-undang) tidak boleh bertentangan dengan norma yang lebih tinggi (UUD 1945). Pasal tersebut juga menegaskan adanya sruktur hukum berupa lembaga Mahkamah Konstitusi yang khusus menganalisis apakah suatu undang-undang atau praktik kenegaraan bertentangan dengan konstitusi atau tidak. Hal ini perlu menjadi perhatian bahwa peraturan yang dikeluarkan selama pandemi Covid-19 ini perlu memperhatikan norma-norma tersebut. Oleh karena itu, peraturan yang dibentuk sebagai dasar dalam penanganan Covid-19 tidak boleh keluar dari asas kesesuaian antara jenis, hierarki, dan materi muatan.

Jika dikembalikan lagi pada peraturan awal dari UUD 1945 hingga UU No. 6 Tahun 2018 tentang Kekarantinaan Kesehatan, Negara memiliki tanggung jawab yang besar terhadapt rakyatnya, sehingga daripada itu, peraturan-peraturan yang berkaitan dengan penangan pandemi Covid-19 ini juga perlu berpedoman kepada dua norma di atas. Oleh karena itu, aturan turunan seperti dalam PP, Perpres, Permen dan lainnya tidak boleh bertentangan dengan UU No. 6 Tahun 2018.

Di dalam Teori Berjenjang, telah ditentukan kelompok-kelompok norma yang dapat menjadi pedoman dalam pembentukan peraturan. Oleh karena itu, dalam pembentukan aturan terkait penanganan pandemi Covid-19 dapat merujuk kelompok norma dalam teori tersebut. Oleh karena itu, pembentuk harus cermat suatu materi muatan harus diatur dalam jenis peraturan apa saja. Sebagai contoh, apabila hendak mengatur hal-hal yang sifatnya membatasi hak asasi manusia, maka tidak boleh pengaturannya dalam jenis instruksi Menteri, namun harus dituangkan dalam jenis undang-undang.

Sungguhpun demikian, apa yang mejadi tujuan bersama dalam pengimplementasiannya adalah kesejahteraan dan keadilan dari hasil peraturan-peraturan yang telah dibuat agar tidak 
terjadi tumpang tindih, dan bentrokan antar peraturan yang lebih tinggi dengan peraturan di bawahnya.

\section{KESIMPULAN}

Wabah Covid-19 menimbulkan dampak yang luar biasa, mulai dari krisis ekonomi serta kesehatan masyarakat yang menjadi fokus pemerintah dalam meminimalisir dampak yang dihasilkan tersebut. Butuh konsistensi pemerintah dalam memilih mana prioritas yang akan dituntaskan terlebih dahulu. Sehingga, berdasarkan dari kajian di atas maka para penulis di sini ingin menyimpulakan;

1. Mengenai konsistensi dari aturan-aturan yang dibuat oleh pemerintah. Misal, dalam perbedaan definisi PSBB yang diatur dalam PP Nomor 21 Tahun 2020 dengan yang diatur dalam UU Kekarantinaan. Kemudian, mengenai Instruksi Menteri Dalam Negeri Nomor 15 Tahun 2021 yang dinilai mengenyampingkan peraturan-peraturan di atasnya.

2. Inkonsistensi yang terlihat kemudian dalam Pasal 55 Ayat (1) UU Nomor 6 tentang Kekarantinaan Kesehatan mengenai hidup dasar orang dan makanan ternak yang dimana hal ini tidak diatur dalam Instruksi Menteri Dalam Negeri. Begitupula dengan Peraturan Menteri Perhubungan No 18 Tahun 2020 yang bertentangan dengan Peraturan Menteri Kesehatan (Permenkes) Nomor 9 Tahun 2020. Terlebih lagi mengenai aturan perjalanan internasional yang dituangkan dalam Surat Edaran (SE) Nomor 47 Tahun 2021 dengan Surat Edaran Satgas Penanganan Covid-19 Nomor 13 Tahun 2021 dimana adanya larangan mudik, namun tidak diikuti dengan konsistensi pemerintah dalam membatasi kedatangan warga negara asing.

Adapun demi tercapainya tujuan ideal dalam menjamin serta melindungi hak-hak konstitusi, negara hukum dan demokrasi yang mampu menampung berbagai dimensi strategis dinamika kehidupan berbangsa dan bernegara yang berkaitan dengan inkonsitensi peraturan di era pandemi Covid-19. Ada beberapa hal yang perlu diperhatikan upaya-upaya dalam mendukung hal tersebut adalah:

1. Pemerintah perlu memperhatikan UUD 1945 dan UU Nomor 6 tentang Kekarantinaan Kesehatan dalam membuat peraturan baru di masa pandemi Covid-19 dan harus mengutamakan kesejahteraan dan keadilan pada muatan peraturan-peraturan yang akan dibuat.

2. Pemerintah pusat dan daerah perlu melakukan sinergi bersama dalam mengatasi pandemi Covid-19 dengan mengedepankan komunikasi yang baik, agar tidak terjadi silang pendapat antara keduanya.

3. Dalam pemberlakukan peraturan mestinya pemerintah memperhatikan teori berjenjeng sebagimana menjadi suatu norma hukum dalam ketatanegaraan sehingga tidak terjadi tumpang tindih peraturan di masa pandemi Covid-19. 


\section{DAFTAR PUSTAKA}

Abdulkhadir Muhammad, 2004, Hukum dan Penelitian Hukum, Bandung: PT Aditya Makti.

Ahmad Sabirin, 2020, Solusi Problematika Hukum Penanganan Pandemi Covid-19 dalam Perspektif Hubungan Pusat dan Daerah, Prosiding National Conference on Law Studies (NCOLS), Universitas Pembangunan Nasional Veteran Jakarta.

Arif Satrio Nugroho, Republika, (2021) https://republika.co.id/berita/qan1sf414/pakarinkonsistensi-peraturan-pengaruhi-perilaku-masyarakat.

Bagir Manan (ed), 1996, Kedaulatan Rakyat, Hak Asasi Manusia dan Negara Hukum, Jakarta: Gaya Media Pratama.

Fauziah Mursidah (Republika), (2021) https://republika.co.id/berita/q8oido377/psbb-depokbekasi-dan-bogor-tak-jauh-beda-dengan-jakarta.

Fitriah, (2021) https://nasional.kompas.com/read/2021/07/01/11141591/ppkm-darurat-jawa-baliberlaku-pada-3-20-juli-2021.

Frans Magnis Suseno, 1999, Etika Politik, Jakarta: Gramedia Pustaka Utama

Maria Farida Indrati, 2007, Ilmu Perundang-Undangan 1; Jenis, Fungsi dan Materi Muatan, Yogyakarta: Kanisius.

Maya Sahurina (Nesosnews), (2021) https://nesosnews.com/ppkm-mulai-diterapkan-11-januaribegini-teknis-pelaksanaannya/.

Miriam Budiardjo, 2006, Dasar-Dasar Ilmu Politik, Jakarta: PT Gramedia Pustaka Utama.

Muhammad Yamin, 1982, Proklamasi dan Konstitusi Republik Indonesia, Jakarta: Ghalia Indonesia.

P. Burgess, (2020) "The Rule of Lore in the Rule of Law: Putting the Problem of the Rule of Law in Context". Hague Journal on the Rule of Law, 12(2), 2020, hlm. 333-361. https://doi.org/10.1007/s40803-019-00096-0 diakses pada tanggal 24 Agustus 2021.

Peraturan Pemerintah Republik Indonesia Nomor 21 Tahun 2020 Tentang Pembatasan Sosial Berskala Besar dalam Rangka Percepatan Penanganan Corona Virus Disease 2019 (Covid-19)

Rahmat, Kompas, (2021), https://nasional.kompas.com/read/2020/04/03/13202731/pembatasansosial-berskala-besar-untuk-cegah-penyebaran-corona-efektifkah?page $=.1$.

Rendika (Kompas), (2021) https://www.kompas.com/tren/read/2021/06/22/160000365/berlakuhari-ini-ini-aturan-lengkap-penebalan-ppkm-mikro-22-juni-5-juli?page=all\#page2.

Rosy (Kompas), (2021) https://www.kompas.com/tren/read/2021/08/17/103100365/aturanlengkap-ppkm-level-4-3-dan-2-di-jawa-bali-yang-berlaku-hingga-23.

Tahir Azhari, 1995, Negara Hukum Indonesia, Jakarta: Universitas Indonesia Press.

Undang-undang Nomor 6 Tahun 2020 Tentang Karantina Kesehatan 